\title{
Perilaku Orang Tua Untuk Mencegah Terjadinya Kenakalan Remaja
}

\author{
Siti Nurhasanah ${ }^{1}$, Imam Subhi ${ }^{2}$, Elvira Sitna Hajar ${ }^{3}$ \\ Fakultas Agama Islam Universitas Azzahra ${ }^{1}$ \\ STIT Pagar Alam Sumsel ${ }^{2}$ \\ Fakultas Ekonomi Universitas Azzahra ${ }^{3}$ \\ ilmimuthia15@gmail.com¹, imamsubhi1002@gmail.com², \\ imranvira@gmail.com ${ }^{3}$
}

\begin{abstract}
ABSTRAK
Perilaku orang tua secara langsung maupun tidak langsung akan dipelajari dan ditiru oleh anak. Bila anak melihat kebiasaan baik dari orang tuanya maka anak akan dengan cepat mencontohnya, demikian sebaliknya bila orang tua berperilaku buruk maka akan ditiru perilakunya oleh anak-anak. Tujuan penelitian ini untuk mengetahui bagaimana seharusnya perilaku orang tua yang dapat mencegah ternjadinya kenakalan pada remaja. Metode penelitian yang digunakan adalah metode penelitian kualitatif dan menggunakan telaah literatur (literature review). Perilaku orang tua yang dapat mencegah terjadinya kenakalan remaja bisa dilihat dari aspek kognitif dan psikososial. Dari aspek kognitif yaitu orang tua selalu bertutur kata lembut, sopan santun ketika berbicara kepada anaknya, orang tua mengawasi anak ketika belajar, mengajarkan dan memberikan contoh langsung dalam hal pendidikan. Dari aspek psikososial orang tua menerapkan pola asuh di keluarga secara terbuka antara orang tua dan anak, menerapkan musyawarah secara kekeluargaan dalam memecahkan masalah, memberikan kebebasan kepada anak dalam berteman, bergaul dengan teman-temanya tetapi dalam pengawasan orang tua.
\end{abstract}

Kata kunci : Perilaku orang tua, kenakalan remaja,

\begin{abstract}
Parents' behavior, directly or indirectly, will be learned and imitated by children. When children see the good habits of their parents, the children will quickly imitate them, and vice versa, if parents behave badly, their behavior will be imitated by the children. The purpose of this study was to find out how parental behavior should be that can prevent delinquency in adolescents. The research method used is a qualitative research method and uses a literature review. Parental behavior that can prevent juvenile delinquency can be seen from the cognitive and psychosocial aspects. From the cognitive aspect, namely parents always speak soft words, politeness when speaking to their children, parents supervise children when learning, teach and provide direct examples in terms of education. From the psychosocial aspect, parents apply open parenting styles in the family between parents and children, apply family discussion in solving problems, give freedom to children in making friends, hanging out with their friends but under parental supervision.
\end{abstract}

Key words: Parents' behavior, delinquency in adolescents 


\section{PENDAHULUAN}

Keluarga merupakan unit sosial terkecil yang utama dan pertama bagi seorang anak, sebelum ia berkenalan dengan dunia sekitarnya, ia akan berkenalan terlebih dahulu dengan situasi keluarga. Pengalaman pergaulan dalam keluarga akan memberikan pengaruh yang sangat besar bagi perkembangan anak untuk masa yang akan datang. Keluargalah yang akan memberikan warna kehidupan seorang anak, baik perilaku, budi pekerti maupun adat kebiasaan sehari-hari. Keluarga jualah tempat dimana seorang anak mendapat tempaaan pertama kali yang kemudian menentukan baik buruk kehidupan setelahnya di masyarakat. (Athiyah Al-Abrasy, 1993, p. 133).

Menurut pakar pendidikan, William Bennett, "Keluarga merupakan tempat yang paling awal dan efektif untuk menjalankan fungsi departemen kesehatan, pendidikan, dan kesejahteraan". Apabila keluarga gagal mengajarkan kejujuran, semangat, keinginan untuk menjadi yang terbaik dan kemampuan-kemampuan dasar, maka akan sulit sekali untuk memperbaikinya perubahan dan pembiasaan yang dilakukan anak sejak dini akan semakin kokoh dan kuat bagi perkembangannya. (Rohinah M.Noor, 2012, p. 128)

Pentingnya pendidikan di dalam keluarga merupakan konsekuensi dari rasa tanggung jawab orang tua terhadap anaknya, keluarga merupakan pendidikaan pertama bagi setiap individu, sifat kepribadian anak akan tumbuh dan terbentuk dalam keluarga. Anak akan menjadi baik dan benar berdasarkan pengaruh sehari-hari dengan orang tua. Hal lain yang sangat penting dalam mendidik anak remaja adalah menjaga hubungan yang cukup positif, akrab dengan anak remaja, membantu dalam perjuangannya dan dalam mencari arti hidup.

Terutama dalam menghadapi anak pada awal masa remaja hal ini berarti harus ada peraturan atau kesepakatan yang masuk akal atau dapat diterapkan pada situasi anak dalam usia tertentu dan perilaku yang diharapkan atau semacam norma perilaku baik di rumah maupun di sekolah. Awal masa remaja merupakan masa dimana si anak secara psikologis terpecah dan mencoba menyatukannya dalam identitas pribadi.

Pada pertengahan dan akhir masa remaja tugas perkembangannya antara lain belajar menentukan prioritas, terarah pada tujuan, dan memanfaatkan waktu serta tenaga. Merupakan kesalahan yang besar, bila mencoba memaksakan tanggung jawab terlalu dini pada anak remaja lainnya beberapa remaja yang nampaknya ada dalam bahaya, jatuh ke dalam jurang emosional, mungkin menggunakan obat bius sedang yang lain kelihatannya cenderung pada pemberontakan terhadap segala kekuasaan atau kewibawaan.(Dr. James E. Gardner,2002, h. 178).

Pada dasarnya tidak terlepas bagaimana bentuk pola asuh yang diterapkan orang tua pada anak-anaknya. sikap dan perilaku yang ditunjukan anak-anak sesunguhnya merupakan cerminan dari bagaimana ia diperlakukan orang tuanya dalam keluarga. Oleh karena itu orang tua harus menghindari perkataan dan sikap yang menunjukan kebohongan, merampas hak orang lain, mencela dan mencaci, mencegah anak agar tidak melalukan hal yang merusak dan menurunkan kehormatan dan harga dirinya juga keluarga. ((Rohinah M.Noor, 2012, p. 157).

Dari pandangan di atas secara biologis, perilaku adalah suatu kegiatan atau aktivitas organisme yang bersangkutan, yang dapat diamati secara langsung maupun tidak langsung. Perilaku adalah suatu kegiatan atau aktivitas organisme (makhluk hidup) yang bersangkutan. Oleh sebab itu, dari sudut pandang biologis 
semua makhluk hidup mulai dari tumbuh-tumbuhan, binatang sampai dengan manusia itu berperilaku, karena mereka mempunyai aktifitas masing-masing.

Perilaku keluarga secara langsung maupun tidak langsung akan dipelajari dan ditiru oleh anak. Anak memodel orang tua dalam keluarga bersikap, bertutur kata, mengekspresikan harapan, tuntutan, dan kritikan satu sama lain, menanggapi dan memecahkan masalah, serta mengungkapan perasaan dan emosinya. Perilaku yang baik akan membawa dampak baik bagi perkembangan anak demikian juga sebaiknya.

Perilaku orang tua secara langsung maupun tidak langsung akan dipelajari dan ditiru oleh anak. Orang tua merupakan lingkungan terdekat yang selalu mengitarinya dan sekaligus menjadi figur dan idola anak. Bila anak melihat kebiasaan baik dari orang tuanya maka anak akan dengan cepat mencontohnya, demikian sebaliknya bila orang tua berperilaku buruk maka akan ditiru perilakunya oleh anak-anak. Anak meniru bagaimana orang tua bersikap, bertutur kata, mengekspresikan harapan, tuntutan, dan kritikan satu sama lain, menanggapi dan memecahkan masalah, serta mengungkapan perasaan dan emosinya. Perilaku yang baik akan membawa dampak baik bagi perkembangan anak demikian juga sebaiknya. Hal ini sesuai dengan pendapat Hurlock yang menyatakan bahwa perlakuan orang tua terhadap anak akan mempengaruhi sikap anak dan perilakunya. Sikap orang tua sangat menentukan hubungan keluarga sebab sekali hubungan terbentuk, ini cenderung bertahan. (Aprilia Tina Lidyasari, p. 2)

Oleh karena itu perilaku orang tua sangat berpengaruh dalam mencegah terjadinya kenakalan remaja, yang dimaksud kenakalan remaja ialah kelainan tingkah laku, perbuatan, atau tindakan remaja yang bersifat asosial bahkan anti sosial yang melanggar norma-norma sosial, agama serta ketentuan hukum yang berlaku dalam masyarakat.(Sofyan S. Willis: 2012,p 89). Sedangkan menurut Dr. Kusumanto dalam Sofyan, "Kenakalan anak dan remaja ialah tingkah laku individu yang bertentangan dengan syarat-syarat dan pendapat umum yang dianggap sebagai acceptable dan baik oleh suatu lingkungan atau hukum yang berlaku di suatu masyarakat yang berkebudayaan". (Sofyan S. Willis: 2012,p. 89)

\section{METODE PENELITIAN}

Menurut bogdan dan taylor bahwa penelitian kualitatif adalah salah satu prosedur penelitian yang menghasilkan data deskriptif berupa ucapan atau tulisan dan perilaku orang-orang yang diamati. Melalui penelitian kualitatfi, peneliti dapat mengenali subjek dan merasakan apa yang mereka alami dalam kehidupan sehari-hari. Penelitian ini juga menggunanakan telaah literatur (literature review) dari berbagai buku, jurnal, dan penelitian yang telah dilakukan sebelumnya. (Robet bogan and steven j. Taylor:1975,p. 21)

\section{HASIL DAN PEMBAHASAN}

Dari sudut biologis perilaku suatu kegiatan atau aktivitas organisme yang bersangkutan yang diamati secara langsung maupun tidak langsung. Perilaku manusia adalah suatu aktivitas manusia itu sendiri Secara operasional perilaku suatu respon organisme atau seseorang terhadap rangsangan dari luar. Perilaku suatu aksi reaksi organisme terhadap lingkungannya. Perilaku adalah tindakan atau perilaku organisme yang dapat diamati bahkan dipelajari. Perilaku manusia pada hakikatatnya adalah proses interaksi individu dengan lingkungannya sebaai manifestasi hayati bahwa ia adalah makhluk hidup. Perilaku manusia adalah 
aktivitas yang timbul karena adanya stimulus dan respon serta dapat diamati secara langsung maupun tidak langsung. (Sunaryo, 2004, p. 3)

\section{Perkembangan Kognitif Perilaku Orang Tua.}

Kognitif yaitu kemampuan individu untuk menghubungkan, menilai dan mempertimbangkan suatu kejadian atau peristiwa. (Ahmad Susanto: 2011, p. 47)

1) Dewasa Awal

Berfikir reflektif, pemikir reflektif terus-menerus mempertanyakan hal-hal yang sudah dianggap fakta, menarik kesimpulan, dan membuat hubunganhubungan. Pemikir reflektif dapat menciptakan sistem intelektual yang rumit mempertemukan ide-ide atau pertimbangan yang saling bersebrangan. Pemikiran pasca formal dicirikan kemampuan untuk menghadapi ketidakpastian, inkonsistensi, kontradiksi, ketidaksempurnaan dan kompromi. Pemikiran pasca informal bersifat fleksibel, terbuka, adaptif dan individualistis. Unsur pengalaman dan kecerdasan praktis oleh karena kecerdasan wawasan dan praktis sangat penting dalam kehidupan individu dewasa. Kecerdasan emosional mengacu pada kemampuan mengenali dan menghadapi perasaan sendiri dan orang lain. seperti optimisme, kecermatan, motivasi, empati, dan kompetensi sosial. (Papalia Olds Feldman, 2009, pp. 138-139)

2) Dewasa Tengah

Peningkatan dalam keahlian terus berlanjut paling tidak selama masa dewasa tengah dan relatif bebas dari kecerdasan umum dan mengalami berbagai penurunan dalam mesin pemrosesan informasi otak. Orang-orang paruh baya bisa jadi agak lama dalam memproses informasi baru mereka dapat mengimbanginya dengan penilaian yang berkembang dari pengalaman. Peran majemuk dan berbagai pilihan yang membingungkan dan tantangan masa paruh baya, seperti kebutuhan untuk menyatukan dan menyeimbangkan tuntutan pekerjaan dan keluarga. (Papalia Olds Feldman, 2009, p. 256)

3) Dewasa Akhir

Fluid inteligence bentuk kecerdasan yang diterapkan pada berbagai masalah baru dan relatif bebas dari pengaruh pendidikan dan budaya. Crystallized inteligence bentuk kecerdasan melibatkan kemampuan mengingat dan menggunakan informasi yang sudah dipelajari sebagian besar bergantung pada latar belakang pendidikan dan budaya. Aktivitas instrumental dalam kehidupan sehari-hari seperti mengisi lembar isian medis, mencari nomor telepon darurat dan membaca label obat lebih terkait dengan Fluid inteligence dibandingkan dengan Crystallized inteligence dan menunjukan penurunan sesuai dengan usia. Lansia cenderung mengalami penurunan dalam kemampuan memproses yang diperlukan untuk menguasai keahlian baru yang kompleks, tetapi berhasil dengan lebih baik dalam tugas yang bergantung pada kebiasaan yang telah terbentuk dan pengetahuan. kemampuan yang sepertinya menurun seiring dengan usia adalah kemampuan mengalihkan perhatian dari satu tugas atau fungsi ke yang lain.

\section{Perkembangan Psikososial perilaku orang tua}

Psikososial yaitu pencapaian kematangan dalam hubungan sosial. Sebagai proses belajar untuk menyesuaikan diri terhadap norma-norma kelompok, moral dan tradisi, meleburkan diri menjadi suatu kesatuan dan saling berkomunikasi dan bekerja sama. (Syamsu Yusuf, 2012, p. 122)

1) Masa Dewasa Muda 
Dalam tahap ini orang dewasa nuda mempelajari cara berinteraksi dengan orang lain secara lebih mendalam. Ketidakmampuan untuk membentuk ikatan sosial yang kuat akan menciptakan rasa kesepian. Beberapa orang mungkin gagal membentuk hubungan yang intim, sehingga menjadi orang yang kesepian atau membentuk banyak hubungan yang dangkal. Bila individu berhasil mengatasi krisis ini keterampilan ego yang diperoleh adalah cinta.

Dewasa awal dituntut untuk saling berkomitmen atau menghadapi rasa pengasingan diri dan keterpakuan diri, mereka mencapai hak otonomi, menikah, dan memilik anak serta memperdalam persahabatan mereka bekerja keras demi karir dan mengabdikan diri pada keluarga mereka. Neuroticism yang menunjukan ketidakstabilan emosional, kecemasan, rasa bermusuhan depresi kesadaran diri, dan kerapuhan. Extraversion memiliki lima aspek yaitu kehangatan mudah bergaul, pencarian kegairahan, dan emosi positif. Opennes to experience mencoba berbagai hal baru dan menerima berbgai ide baru. (Papalia Feldman:2009,p. 173)

2) Masa Dewasa Menengah

Pada tahap ini individu mulai menyerahkan dirinya pada orang lain. Terkadang dalam bentuk seperti membesarkan dan mengasuh anak, namun juga berbentuk beberapa kegiatan lain seperti kegiatan sosial. Ketidakmampuan untuk memiliki pandangan generatif akan menciptakan perasaan bahwa hidup ini tidak beharga dan membosankan. Individu seperti ini mungkin berhasil memperoleh tujuan-tujuan duniawi, tetapi di balik kesuksesan ia merasa hidupnya tidak berarti. Bila individu berhasil mengatasi krisisi pada masa ini maka keterampilan egonya adalah perhatian. Kepedulian orang dewasa yang matang untuk membangun dan membimbing generasi berikutnya atau jika tidak mengalami ketersendatan (sebuah perasaan ketidakaktifan atau ketiadaan hidup). (Papalia Feldman:2009,p. 292)

3) Masa Dewasa Akhir

Pada tahap ini mereka juga dapat mengingat kembali masa lalu dan melihat makna ketentraman dan integritas. Pencarian saat ini adalah untuk mengitegrasikan tujuan hidup yang telah dikejar selama bertahun-tahun. Kegagalan melewati tahapan ini akan menyebabkan rasa putus asa.(Sumanto, 2014,pp. 127-128)

Tabel 3.1

Tugas-tugas Perkembangan Perilaku Orang Tua

\begin{tabular}{|c|c|c|}
\hline Dewasa Awal & Dewasa Menengah & Dewasa Akhir \\
\hline $\begin{array}{l}\text { 1. Mulai bekerja } \\
\text { 2. Memilih pasangan } \\
\text { hidup } \\
\text { 3. Belajar hidup dengan } \\
\text { suami/istri } \\
\text { 4. Mulai membentuk } \\
\text { keluarga } \\
\text { 5. Mengasuh anak } \\
\text { 6. Mengelola rumah } \\
\text { tangga } \\
\text { 7. Menemukan kelompok } \\
\text { sosial yang } \\
\text { menyenangkan }\end{array}$ & $\begin{array}{l}\text { 1. Menerima dan } \\
\text { menyesuaikan diri } \\
\text { terhadap perubahan } \\
\text { fisik dan fisiologis } \\
\text { 2. Menghubungkan diri } \\
\text { sendiri dengan } \\
\text { pasangan individu } \\
\text { sebagai individu } \\
\text { 3. Membantu anak- } \\
\text { anaknya yang sudah } \\
\text { remaja belajar } \\
\text { menjadi orang yang } \\
\text { bertanggung jawab } \\
\text { dan bahagia } \\
\text { 4. Mencapai dan }\end{array}$ & $\begin{array}{l}\text { 1. Menyesuaikan diri } \\
\text { dengan } \\
\text { menurunnya } \\
\text { kekuatan fisik dan } \\
\text { kesehatan secara } \\
\text { bertahap } \\
\text { 2. Menyesuaikan diri } \\
\text { dengan } \\
\text { berkurangnya } \\
\text { pendapat } \\
\text { 3. Menyesuaikan diri } \\
\text { dengan kematian } \\
\text { pasangan hidup } \\
\text { 4. Menjadi anggota } \\
\text { kelompok sebaya }\end{array}$ \\
\hline
\end{tabular}


Perilaku Orang Tua Untuk,Mencegah ... I

\begin{tabular}{|l|l|l|}
\hline Dewasa Awal & Dewasa Menengah & Dewasa Akhir \\
\hline & mempertahankan & dan mengikuti \\
& prestasi yang & pertemuan- \\
& memuaskan dalam & pertemuan sosial \\
& karier pekerjaan & 5. Menyesuaikan diri \\
& 5. Mengembangkan & dengan peran sosial \\
& kegiatan-kegiatan & secara fleksibel \\
& waktu yang positif & 6. Menyesuaikan dan \\
& 6. Mencapai tanggung & memperlakukan \\
& jawab sosial dan & anak-anak tidak \\
& warga negara secara & seperti ketika masih \\
& penuh & kecil \\
\hline
\end{tabular}

Sumber : Sumanto:2014,p. 116

Pada Al Quran surat Lukman ayat 15-17 telah diatur bagaimana Perilaku Orang Tua dalam mendidik anaknya, berikut adalah terjemahannya :

"Dan jika keduanya memaksamu untuk mempersekutukan dengan aku sesuatu yang tidak ada pengetahuanmu tentang itu, Maka janganlah kamu mengikuti keduanya, dan pergaulilah keduanya di dunia dengan baik, dan ikutilah jalan orang yang kembali kepada-Ku, kemudian hanya kepada-Kulah kembalimu, Maka Kuberitakan kepadamu apa yang telah kamu kerjakan.(Luqman berkata): "Hai anakku, Sesungguhnya jika ada (sesuatu perbuatan) seberat biji sawi, dan berada dalam batu atau di langit atau di dalam bumi, niscaya Allah akan mendatangkannya (membalasinya). Sesungguhnya Allah Maha Halus lagi Maha mengetahui. Hai anakku, dirikanlah shalat dan suruhlah (manusia) mengerjakan yang baik dan cegahlah (mereka) dari perbuatan yang mungkar dan bersabarlah terhadap apa yang menimpa kamu. Sesungguhnya yang demikian itu Termasuk hal-hal yang diwajibkan (oleh Allah).

Berdasarkan ayat di atas dapat di ambil kesimpulan bahwa perilaku orang tua dalam mendidik anak-anaknya merupakan cerminan dan contoh untuk anakanak mereka. Perilaku orang tua ditiru dan dicontoh oleh anaknya, jika perilaku orang tua baik atau buruk anak pun ikut mencontohnya. Setiap orang tua pasti mendidik dan mengajarkan kebaikan kepada anaknya oleh karena itu perilaku orang tua dalam hal ini dapat mencegah terjadinya kenakalan remaja, terjadinya kenakalan remaja akibat perilaku orang tuanya dalam mendidik anaknya.

Tabel 3.2

Proses Pembentukan dan Perubahan Perilaku pada orang dewasa

\begin{tabular}{|c|c|c|c|c|}
\hline \multicolumn{5}{|c|}{ INDIKATOR } \\
\hline No & Usia & Fisik & Kognitif & Psikososial \\
\hline 1. & $\begin{array}{l}\text { Dewasa } \\
\text { Muda } \\
20-40 \\
\text { tahun }\end{array}$ & $\begin{array}{l}\text { Fungsi fisik } \\
\text { mencapai } \\
\text { puncaknya } \\
\text { kemudian sedikit } \\
\text { menurun. Pilihan } \\
\text { gaya hidup } \\
\text { memengaruhi } \\
\text { kesehatan }\end{array}$ & $\begin{array}{l}\text { Pikiran menjadi } \\
\text { makin rumit. } \\
\text { Membuat pilihan } \\
\text { pendidikan dan } \\
\text { pekerjaan. }\end{array}$ & $\begin{array}{l}\text { Berbagai } \\
\text { keputusan } \\
\text { mengenai } \\
\text { hubungan yang } \\
\text { intim dan gaya } \\
\text { hidup pribadi } \\
\text { dibuat. } \\
\text { Kebanyakan }\end{array}$ \\
\hline
\end{tabular}




\begin{tabular}{|c|c|c|c|c|}
\hline & & & & $\begin{array}{l}\text { orang menikah, } \\
\text { dan kebanyakan } \\
\text { menjadi orang } \\
\text { tua. }\end{array}$ \\
\hline 2. & $\begin{array}{l}\text { Dewasa } \\
\text { Tengah } \\
40-65 \\
\text { tahun }\end{array}$ & $\begin{array}{l}\text { Kemunduran } \\
\text { kemampuan } \\
\text { sensoris, kesehatan, } \\
\text { stamina dan } \\
\text { kekuatan yang } \\
\text { lambat dimulai } \\
\text { tetapi perbedaan } \\
\text { individual melebar. } \\
\text { Perubahan } \\
\text { hormonal bisa } \\
\text { mengarah pada } \\
\text { penurunan yang } \\
\text { lamabat pada hasrat } \\
\text { seksual. Wanita } \\
\text { mengalami } \\
\text { menopause. }\end{array}$ & $\begin{array}{l}\text { Kemampuan } \\
\text { mental mencapai } \\
\text { puncaknya, } \\
\text { kepakaran dan } \\
\text { keterampilan } \\
\text { pemecahan } \\
\text { masalah praktis } \\
\text { tinggi. Hasil kreatif } \\
\text { dapat menurun, } \\
\text { tetapi meningkat } \\
\text { dalam kualitas. } \\
\text { Keberhasilan karir } \\
\text { bisa mencapai } \\
\text { puncaknya atau } \\
\text { perubahan karir } \\
\text { bisa muncul. }\end{array}$ & $\begin{array}{l}\text { Jaringan sosial } \\
\text { cenderung } \\
\text { mengecil, tetapi } \\
\text { lebih intim. } \\
\text { Tanggung jawab } \\
\text { ganda mengasuh } \\
\text { anak dan orang } \\
\text { tua bisa } \\
\text { menyebabkan } \\
\text { stres. Anak-anak } \\
\text { pergi dari rumah } \\
\text { membuat adanya } \\
\text { empty nest. }\end{array}$ \\
\hline 3. & $\begin{array}{l}\text { Dewasa } \\
\text { Tua } 65 \\
\text { tahun } \\
\text { ke atas }\end{array}$ & $\begin{array}{l}\text { Kebanyakan lansia } \\
\text { sehat dan aktif, } \\
\text { meskipun } \\
\text { kesehatan dan } \\
\text { kemampuan fisik } \\
\text { secara umum } \\
\text { menurun. } \\
\text { Kebutuhan tidur } \\
\text { menurun. Disfungsi } \\
\text { seksual dan } \\
\text { penyakit kronis } \\
\text { menjadi lebih } \\
\text { lazim. }\end{array}$ & $\begin{array}{l}\text { Kebanyakan lansia } \\
\text { waspada secara } \\
\text { mental. Meskipun } \\
\text { kecerdasan dan } \\
\text { ingatan merosot } \\
\text { dalam beberapa } \\
\text { area, kebanyakan } \\
\text { orang menemukan } \\
\text { cara untuk } \\
\text { mengompensasiny } \\
\text { a }\end{array}$ & $\begin{array}{l}\text { Hubungan dengan } \\
\text { keluarga dan } \\
\text { teman dekat dapat } \\
\text { memberikan } \\
\text { dukungan yang } \\
\text { penting. }\end{array}$ \\
\hline
\end{tabular}

Sumber : Papalia. Olds. Feldman, 2009

Perilaku orang tua terbentuk dan dipengaruhi oleh tingkatan usia yang dibagi menjadi 3 rentang usia yaitu dewasa awal, dewasa tengah dan dewasa akhir. Indikator kognitif perilaku orang tua dalam hal ini membimbing anak-anaknya, meniti karir, pikiran menjadi rumit, kecerdasan ingatan dan kondisi fisik mulai menurun. Indikator psikososial perilaku orang tua adalah mengelola rumah tangga, mengasuh dan mendidik anak, memikul tanggung jawab sebagai warga negara, membuat hubungan dengan suatu kelompok sosial tertentu.

Perilaku orang tua yang dapat mencegah kenakalan remaja bisa dilakukan dengan memberikan kebebasan anak untuk menyalurkan hobi sudah sangat baik yaitu mengizinkan anak untuk mengikuti kegiatan esktrakurikuler sekolah atau menyaurkan hobinya. Ketika berakhir pekan atau weekend orang tua dapat meluangkan waktunya untuk berkumpul atau berlibur ke suatu tempat bersama keluarganya. Orang tua dapat mengajarkan keterampilan seperti menjahit, memasak, melukis 
dan lain-lain agar anak-anak memiliki kesibukan dalan menyalurkan hobi dan keterampilan yang disukai anak-anak.

Pada indikator Psikososial, Perilaku orang tua dalam menerapkan pola asuh di keluarga secara terbuka antara orang tua dan anak menunjukan orang tua bersikap terbuka dan tidak tertutup. Dalam hal memecahkan masalah perilaku orang tua menerapkan musyawarah secara kekeluargaan hal ini menunjukan orang tua bersikap demokratis. Dalam hal keagamaan dan bersosialisasi orang tua mengajak anak untuk mengikuti kegiatan keagamaan seperti majelis khusus remaja atau remaja masjid, mendengarkan ceramah agama di masjid, mengikuti kajian islam, Orang tua membiasakan anak untuk melaksanakan ibadah yang biasa dilakukan dalam keluarga seperti mengaji, sholat dan lainnya. Ini menunjukan orang tua sangat disiplin tentang agama, bersifat religius dalam pendidikan agama.

Dalam hal kedisiplinan orang tua menerapkan batasan jam bermain anak ketika di luar rumah sangatlah baik ini menunjukan orang tua memberikan kebebasan anak bermain tetapi dalam peraturan orang tua dengan memberikan batasan jam bermain. Orang tua juga memberikan kebebasan kepada anak untuk berteman, bergaul dengan teman-temannya Orang tua dalam hal pengawasan ketika anak membuka internet, membaca media cetak dan lain-lain. Orang tua dapat membiasakan makan bersama di meja makan dengan seluruh anggota keluarga untuk mempererat rasa kebersamaan.

Perilaku orang tua yang dibagi menjadi aspek kognitif dan psikososial dalam mencegah kenakalan remaja dinyatakan mampu mencegah terjadinya kenakalan remaja ini terbukti bahwa perilaku orang tua mempunyai dampak yang sangat besar bagi remaja. adapun perilaku orang tua yang dapat mencegah dari aspek kognitif adalah orang tua selalu bertutur kata lembut, sopan santun ketika berbicara kepada anaknya, orang tua mengawasi anak ketika belajar, mengajarkan dan memberikan contoh langsung dalam hal pendidikan agama seperti: sholat berjamaah, membaca al quran dll, dapat membagi waktu antrara pekerjaan dan keluarga seperti membantu PR/mengawasi belajar, menyiapkan sarapan, masak dan lain-lain, memberikan kebebasan anak untuk menyalurkan hobi seperti mengikuti eskul dan les, membiasakan/menerapkan anak untk bertanggung jawab atas dirinya sendiri seperti merapikan tempat tidur, dapat mengatur waktu antara bermain dan belajar.

Dari aspek psikososial adalah menerapkan pola asuh di keluarga secara terbuka antara orang tua dan anak, menerapkan musyawarah secara kekeluargaan dalam memecahkan masalah, mengajarkan anak mengaji di rumah atau mengikutsertakan mengaji di masjid/musholla atau ditambah pengajaran dari guru privat mengaji, orang tua menerapkan batasan jam bermain anak ketika di luar rumah, memberikan kebebasan kepada anak dalam berteman, bergaul dengan teman-temanya tetapi dalam pengawasan orang tua, mengajak anak untuk mengikuti kegiatan keagamaan seperti majelis khusus remaja/remaja masjid, mendengarkan ceramah agama di masjid, mengikuti kajian islam. 


\section{KESIMPULAN}

Perilaku orang tua dinyatakan mampu mencegah terjadinya kenakalan remaja dan mempunyai dampak yang sangat besar bagi remaja. Perilaku orang tua dalam mencegah kenakalan remaja dibagi menjadi aspek kognitif dan psikososial ini terbukti bahwa perilaku orang tua Perilaku orang tua dapat dinyatakan mampu mencegah terjadinya kenakalan remaja. Perilaku orang tua yang dapat mencegah dari aspek kognitif adalah orang tua selalu bertutur kata lembut, sopan santun ketika berbicara kepada anaknya, orang tua mengawasi anak ketika belajar, mengajarkan dan memberikan contoh langsung dalam hal pendidikan agama seperti: sholat berjamaah, membaca al-quran dll. Dari aspek psikososial adalah menerapkan pola asuh di keluarga secara terbuka antara orang tua dan anak, menerapkan musyawarah secara kekeluargaan dalam memecahkan masalah dll.

\section{DAFTAR PUSTAKA}

Al-Abrasy, Athiyah. (1993). Dasar-dasar Pokok Pendidikan Islam, Jakarta: Bulan Bintang

A1-Qur'an dan Terjemahannya. (2019). Departemen Agama RI.Bandung: CV Darus Sunnah

Bogan Robert and Steven J. Taylor. (1975). Interoduction To Qualitative Research Methods: Aphenomenenological Approach To The Social Science (New York: A Willey- interscience publication)

Feldman Olds Papalia. (2009). Human Development Perkembangan Manusia Edisi 10 Buku 2, Jakarta: Salemba Humanika

Gardner E. James. (2002). Memahami Gejolak Masa Remaja, Jakarta: Mitra Utama

http//deslanikn.blogspot.com/2010/07/teori-perilaku-psikologi.html

http//softlinemedia.blogspot.com/2013/0/kenakalan-remaja-dan-solusinya.html

Kartono Kartini. (2007). Psikologi Anak Psikologi Perkembangan, Bandung: Mandar Maju

Lidyasari Tina Aprilia, Artikel Pola Asuh Otoritas Sebagai Sarana Pembentukan Karakter Anak dalam Setting Keluarga.

L, Zulkifli. (2009). Psikologi Perkembangan, Bandung: PT Remaja Rosdakarya

Noor, M.Rohinah. (2012). Mengembangkan Karakter Anak Secara Efektif di Sekolah dan di Rumah, Jakarta: PT Pustaka Insan Madani.

Satiadarma P, Monty. (2001.) Persepsi Orang Tua Membentuk Perilaku Anak Dampak Pygmalion dalam Keluarga, Jakarta: Pustaka Obor

Sarwono, W. Sarlito. (2010). Pengantar Psikologi Umum, Jakarta: Rajawali Pers

Sudarsono, (2012). Kenakalan Remaja Prevensi Rehabilitasi dan Resosialissi, Jakarta: Rineka Cipta,

Sumanto. (2014). Psikologi Perkembangan Fungsi dan Teori, Yogyakarta: Caps,

Sarwono W Sarlito. (2011). Psikologi Remaja, Jakarta: Rajawali Pers

Susanto Ahmad. (2011). Perkembagan Anak Usia Dini Pengantar Dalam Berbagai Aspeknya, Jakarta: Kencana Pranemedia Group 
Yusuf Syamsu. (2012). Psikologi Perkembangan Anak dan Remaja, Bandung: PT Remaja Rosdakarya.

Willis S, Sofyan. (2012). Remaja dan Masalahnya, Bandung: Alfabeta. 